\title{
Tomato pomace silage as a potential new supplementary food for game species
}

\author{
Judit Galló ${ }^{1}$, Csaba Fernye², Szilvia Orosz ${ }^{3}$ Krisztián Katona ${ }^{1}$, László Szemethy ${ }^{1}$ \\ ${ }^{1}$ Szent István University, Faculty of Agricultural and Environmental Sciences, Institute for Wildlife Conservation, Gödöllő, \\ Hungary \\ ${ }^{2}$ Szent István University, Faculty of Agricultural and Environmental Sciences, Department of Nutrition \\ Gödöllö, Hungary \\ ${ }^{3}$ Livestock Performance Testing Ltd, Feed Laboratory, Gödöllő, Hungary \\ e-mail: gallojudit@gmail.com
}

\begin{abstract}
There is a debate whether supplementary feeding of game species is necessary, and what type of supplementary food is appropriate for them. In our study a new type of supplemental food for wild game species was evaluated. Fresh tomato pomace mixed with ground maize grains ( $20 \% \mathrm{w} / \mathrm{w}$ on a fresh basis) was baled. Different additive treatments were made and crude protein and crude fibre content and fermentation profile were evaluated. Consumption of tomato pomace silage by wild ungulates was also measured. Ground maize grains increased the dry matter content and crude protein : crude fibre ratio of tomato pomace. Tomato pomace mixed silage had a limited fermentation capacity with appropriate $\mathrm{pH}$ and fermentation acid content. The special baling technology was suitable to form well-shaped bales. In the investigated hunting preserve tomato pomace was the dominant food component in the diet of ungulate species. According to our results, tomato pomace could provide suitable quality supplementary food for large game species.
\end{abstract}

Key words: by-product, faeces, fermentation, micro-histological analysis, wild ruminants

\section{Introduction}

There is a debate whether supplementary feeding of game species is necessary (Putman and Staines 2004, Dubois and Fraser 2013, Katona et al. 2014, Steyaert et al. 2014), and if it is what type of supplementary food is appropriate for them. Supplementary winter feeding of game species is a common practice in Europe (Rajský et al. 2008, Csányi and Lehoczki 2010) and parts of North America (Putman and Staines 2004, Weston 2012). Efficacy of supplementary feeding is very controversial, however, with regards to this we have to make a distinction between the case of free-ranging and fenced populations. According to Putman and Staines (2004) supplementary feeding on open range has little effect on fecundity and body weight of red deer; and its effect on antler size and quality and on survival is also equivocal.

Katona et al. (2014) revealed that the proportion of supplementary food (apple pomace and maize silage) was low in the diet of red deer in different unfenced areas. However, the situation is different in fenced areas, where limited space and food supply is accessible. Moreover in hunting preserves red deer (Cervus elaphus), fallow deer (Dama dama), mouflon (Ovis aries musimon) or wild boar (Sus scrofa) can occur in a relatively higher density than in unfenced areas (Mátrai et al. 2013). Fenced ungulates can degrade the vegetation, and the regeneration of the browse species becomes limited (Asnani et al. 2006, White 2012, Mátrai et al. 2013, Szemethy et al. 2013). Thus, in most cases some form of artificial feeding is required in the enclosures (Roosendaal 1992, Dubois and Fraser 2013). Due to the low availability of natural food supplies supplementary food appeared in a higher proportion in the diet of red deer in fenced than in unfenced areas according to Szemethy et al. (2013).

Nevertheless, the supplementary food provided could often be inappropriate for wild ruminant species. In Hungary, the most common supplementary foods are roughages (maize silage, haylage), grains and by-products (e.g. apple pomace) (Csányi 2015). Some of them may cause digestive problems in deer species. Feeding low quality hay may lead to acute digestive impaction and ulceration in deer because of their relatively small digestive system compared to that of sheep or goats. Therefore, deer species require more nutritious, easily digestible forage (Schoonveld et al. 1974). Feeding grains as high energy food (rich in carbohydrates) to animals adapted to natural forages may cause rumenitis (Woolf and Kradel 1977), or even death (Wobeser and Runge 1975, Owens et al. 1998, Butler et al. 2008). In addition, stripping of bark can be higher in areas where the supplementary food was primarily grain, which is deficient in fibre (Putman and Staines 2004). A safe supplemental feed must allow animals to switch from natural to supplementary food and from supplementary food to natural forage without 
causing digestive upsets (Baker and Hobbs 1985). To assure an appropriate food without health risk for deer, we have to know their dietary requirements and food selection strategies.

According to Mátrai et al. (2004) red deer consume plants with high protein and relatively low crude fibre content, consequently the crude protein : crude fibre ratio (CP/CF) should reach or exceed 1-1.5, which can be optimal for them. González-Hernández and Silva-Pando (1999) showed that the crude protein content of plants increases during the growing season, its peak is in spring-summer, but it declines during fall and winter. Therefore, in this last period when the protein content in plants falls below the requirements of ungulates, providing supplementary fodder of relatively high crude protein and energy content and moderate crude fibre content could be beneficial for wild ruminants. Several authors stated that the basic determinants of herbivore food choice are crude protein and crude fibre content (Chen et al. 1998, Gonzáles-Hernandez and Silva-Pando 1999, Szemethy et al. 2003).

Fodders that are rich in digestible carbohydrates (energy) and protein and also contain enough water satisfying the needs of ungulates may be fruits, cabbage and vegetables (Rehbinder and Ciszuk 1985). A potential good solution may be a tomato by-product. Tomato pomace appears in canning factories as a secondary product, it contains the tomato peels, crushed seeds and small amounts of pulp that remains after the processing of tomato. Supplementary feed can be very expensive, but a secondary product is presumably cheaper than a conventional one. It has some advantages. It derives from tomato lands, so it does not require more land from forests (ecological footprint). It is considered as an environmental pollutant, its destruction has to be paid for by the factory, but after ensiling or drying it can be used as a fodder. Wet tomato pomace contains valuable seed-oil that increases the energy content of the pomace.

Ensiled tomato pomace can be a potential protein- and energy source in animal nutrition (Hadjipanayiotou 1994). It is a good source of fibre (Elliott et al. 1981), and it can be used as a substitute for good quality roughages (Omer and Abdel-Magid 2015). Hasimoglu et al. (1979) reported that digestible crude protein content of tomato pulp was similar to that of good quality grass hay. Tahmasbi et al. (2002) found that increasing tomato pomace level in maize silage increased the crude protein digestibility of the silage. In sacco protein degradability of dried tomato pomace in the rumen is quite high, from 65-70\% (Chumpawadee 2009) to 76-78\% (Valizadeh and Sobhanirad 2009). However, water content of tomato pulp generates large quantities of effluent (Barroso et al. 2005), and its $\mathrm{pH}$ level does not sufficiently decrease to the safety level (Hadjipanayioutou 1994). Hence, it is recommended to add dry material to the pulp (Barroso et al. 2005). Ziaei and Molaei (2010) concluded that tomato pomace mixed with 5 or $10 \%$ wheat straw on a fresh basis preserved and fermented well. Denek and Can (2006) used wheat straw and wheat grain as additives, and they found that tomato pomace silages fermented and preserved well with these additions, and this type of silage can be a source of good quality roughage for sheep. However, the high moisture content of tomato pomace makes its fermentation and long term storage difficult. The description of a relatively new development, the 'special baling technology' as described by Orosz et al. (2008), could solve this problem, and makes the large-scale ensiling technique of this material possible.

Although tomato pomace can be used in animal nutrition, its utilisation is competitive in those countries, where it is generated during the whole year and can be sun-dried. In Hungary, tomato pomace is generated seasonally (late summer-fall), and its quantity is not so big (approximately $140000 \mathrm{t}$ tomato fruit in 2013; FAOSTAT 2013) that its utilisation in animal husbandry may be worthwhile. Because of its quantity and generating period, it can be suitably used for game nutrition as a supplementary fodder.

The aim of our research was to make tomato pomace silage of optimal nutritional value (especially regarding the crude protein and crude fibre content) for ungulate species. To achieve this aim, the tomato pomace was mixed with different additives and a large-scale baling technique was adapted. We assessed the nutritional value and fermentation profile of tomato pomace silage and evaluated its consumption by different wild ungulate species adapted to natural forage diet.

We hypothesised that 1 ) tomato pomace mixed with ground maize grains increases the dry matter content, and improves $\mathrm{CP} / \mathrm{CF}$ of the material above the optimal 1.0 value; 2 ) tomato pomace mixed with additives ferment well represented by low $\mathrm{pH}$ and appropriate acid contents 3 ) despite the small particle size of tomato pomace and ground maize grains, ensilage technology can be achieved by a baler-wrapper; 4) ungulate species will consume this new type of fodder, even in a higher quantity than traditional supplementary foods. 


\section{Material and methods}

Study area

Tomato pomace was baled in Hatvan, Hungary in the area of a tomato processing company; where the ensiling experiment was also carried out. Feeding study was conducted in a hunting preserve in Bodony, Hungary $\left(47^{\circ} 58^{\prime} \mathrm{N}\right.$, $\left.20^{\circ} 01^{\prime} \mathrm{E}\right)$. The hunting preserve is located in the North Hungarian Mountains. This fenced area is 275 ha. There are red deer, fallow deer, mouflon and wild boar. The estimated number of individuals was 60, 50, 180 and 120 , respectively. Approximately $40 \%$ of the area is covered by woodland, where the dominant tree species are black locust (Robinia pseudoacacia) and pine (Pinus spp.). The rest of the area contains reeds, shrubs, grass fields and game plots. The dominant shrub species are blackthorn (Prunus spinosa) and hawthorn (Crataegus monogyna). The topography of the area is characterized with an average elevation of $400 \mathrm{~m}$; brown forest soil is typical. The average annual temperature is $8.5^{\circ} \mathrm{C}$; annual temperature during the vegetation period is $15^{\circ} \mathrm{C}$.

\section{Fermentation process}

The experiment was conducted using wet (fresh) tomato pomace obtained from a tomato processing company at Hatvan, Hungary in September 2009. Ground maize grains were added to improve nutrient- and energy content of the silage. Baling was carried out by a Göweil LT Master fixed-chamber baler-wrapper machine, applying a pressure of 130 bars during the baling process. Film wrap ( $25 \mu \mathrm{m}$ thick) was applied $70 \%$ pre-stretched, with 6 layers (by 28 turns). We baled 21.7 t fresh tomato pomace mixed with 5.8 t ground maize grains resulting in 23 round bales.

Experimental treatments were as follows: mixture of tomato pomace and dried ground maize grains in $20 \%$ on wet basis as control ( 6 bales); mixture of tomato pomace and ground maize grains ( $20 \%$ on wet basis) treated with $0.5 \%$ salt (feed salt for animals; S; 8 bales); mixture of tomato pomace and ground maize grains ( $20 \%$ on wet basis) treated with Sil All 4x4 silage inoculant (produced by Alltech, Inc.; Enterococcus faecium, Pediococcus acidilactici, Lactobacillus plantarum, Lactobacillus salivarius, and amylase, hemicellulase, cellulase, pentosanase; SI; 9 bales). The application rate was $5 \mathrm{~g} \mathrm{ton}^{-1}, 10^{5} \mathrm{CFU} \mathrm{g}^{-1}$ fresh material, sprayed in 2 litre water ton ${ }^{-1}$. The purpose of salt addition was to increase the mineral content of the silage fed during wintertime, and to determine the possible antibacterial and antifungal effect of the salt. Bales were punctured within one day after baling, and effluent was collected and measured. Fresh composite sample of each treatment was analyzed for crude fibre, crude protein, starch, total carotene, aerobic mesophyl bacteria and moulds.

On the $70^{\text {th }}$ day of fermentation composite samples were analyzed for crude fibre, crude protein, starch and total carotene. Silage samples ( $n=3$ for each treatment) were also assayed for $\mathrm{pH}$, lactic and volatile fatty acid composition. The dry matter content of the fresh materials and silages was determined by oven-drying at $60^{\circ} \mathrm{C}$. Laboratory dry matter was measured by oven-drying for $4 \mathrm{hr}$ at $103 \pm 2{ }^{\circ} \mathrm{C}$ according to the Hungarian Standard (MSZ ISO 6496:2001). Nitrogen (N) content was measured by the Kjeldahl method according to the Hungarian Standard (MSZ 6830-4:1981). The CP was calculated as Nx6.25. The crude fibre and carotene content were measured according to the Hungarian Standard Methods (MSZ EN ISO 6865:2001 and MSZ 6830-14:1984, respectively). Polarimetric method was used to determine the starch content according to the Hungarian Standard (MSZ 6830-18:1988). Silage sample (wet basis) of $50 \mathrm{~g}$ was blended with $500 \mathrm{ml}$ distilled water for $5 \mathrm{~min}$ and filtered. The filtered liquid was used for $\mathrm{pH}$, lactic acid and volatile fatty acid determination. The $\mathrm{pH}$ was directly measured using a $\mathrm{pH}$ meter. The concentrations of volatile fatty acid (VFA) and lactic acid were analyzed by gas chromatography (MSZ 683039:1986). Aerobic mesophilic bacteria, moulds and yeast were determined according to International and Hungarian Standard and the results were expressed as colony-forming units per gram (CFU g-1 on a fresh basis) (ISO 4833:2003 and MSZ ISO 7954:1999, respectively). Fleig points of the different treatments were calculated by the following equation reported by Kilic (1984, cited by Denek and Can 2006):

Fleig points $=220+(2 \times \mathrm{DM} \%-15)-40 \times \mathrm{pH}$

where: DM - Dry matter content of the silage (\%)

Based on the calculated values derived from several investigations of net energy content of tomato pomace and ground maize grains published in the Hungarian Food Codex (2004), net energy content of mixed tomato pomace silage was calculated. The mixing ratio was taken into consideration on a dry matter basis. 


\begin{abstract}
Feeding study
The feeding experiment was carried out in Bodony between November 2009 and March 2010. All treatments for tomato pomace baled silage were placed in three feeding plots during this period in approx. every 2 or 3 weeks. Maize silage was also placed on the same feeding plots in order to find out which forage is preferred by game species. Maize grain was scattered on the ground for wild boars several times. Consumption and disappearance of silages were visually observed on a daily basis. A week after the placing of the two different types of silage (tomato pomace vs. maize silage) on feeding plots, ten individual fresh faecal pellet groups were collected from each game species in each time along 8 transect lines, which were $1 \mathrm{~m}$ wide and $50 \mathrm{~m}$ long and originated from the feeding plot. Ten faecal samples from one feeding plot from one ungulate species were bulked as a composite sample, and the averaged values of the 3 feeding plots were used. The samples were collected in bags and frozen until analysis. Three subsamples were made from every composite sample, and the average of them was considered.
\end{abstract}

According to Alipayo et al. (1992) faecal analysis can be a useful tool to estimate diet composition of ruminants, accuracy of faecal analysis is little influenced by digestibility. Katona et al. (2014) reported that microscopic analysis could be more accurate than the macroscopic one to reveal the consumption of supplementary feed by ungulates. According to this statement, the diet composition was determined by microhistological faecal analysis (Katona and Altbäcker 2002) using a microhistological anatomical key (Mátrai et al. 1986). The samples were thawed at room temperature prior to analysis. A subsample was boiled in $2 \mathrm{ml}$ of $\mathrm{HNO}_{3}$ for 3 minutes. After cooling the sample, $2 \mathrm{ml}$ water was added to the sample. Epidermis fragments were removed and dispersed into a mixture of $0.1 \mathrm{ml}$ glycerine and $0.05 \mathrm{ml}$ of $0.2 \%$ Toluidin-Blue and placed on slides. Samples were examined by systematic scanning under $100 \times$ and $400 \times$ magnifications. One hundred epidermis fragments were identified using a reference collection of plant species occurring in the study area. Five categories were determined: tomato, maize (silage and grain), monocotyledons (grasses), dicotyledonous (herbs) and woody plants.

The study was conducted in an ethically acceptable manner. The following Acts were taken into consideration: a) Act of XXVIII of 1998 on the protection and sparing of animals; b) Law No LV of 1996 on the protection, management and hunting of wildlife.

\title{
Statistical analyses
}

The fermentation characteristics of the silages were analysed for their statistical significance (ANOVA and Tukey post-hoc test) with SPSS (version PASW Statistics 18). In the determination of diet composition, ANOVA test with Tukey post-hoc test or Dunnett T3 post hoc test were used to make statistical comparisons.

\section{Results}

\section{Raw material}

Nutrient and carotene content and microbiological analysis of the fresh tomato pomace and the different treatments are presented in Table 1. Fresh tomato pomace had a relatively low dry matter content (26.9\%) with a relatively high crude protein (19.8\%) and high crude fibre (40\%) content. It contained only $2.4 \%$ starch. Mixing tomato pomace with $20 \%$ ground maize grains increased the dry matter content by $35 \%$, and decreased its crude protein and crude fibre content by $20 \%$ and $40 \%$, respectively. Since the decrease of crude fibre content was higher than the decrease in protein content, CP/CF increased by $35 \%$ compared to fresh tomato pomace. There were no considerable differences between the different additive treatments ( $T P+G M G, T P+G M G+S, T P+G M G+S I)$ related to dry matter, crude protein and crude fibre content, so their CP/CF was also similar.

Fresh tomato pomace mixed with $20 \%$ hygroscopic dried ground maize grains increased the net energy content for maintenance $\left(\mathrm{NE}_{m}\right)$ by $40 \%$. The calculated lactation net energy content ( $\mathrm{NE}_{1} 6.33 \mathrm{MJ} \mathrm{kg}^{-1} \mathrm{DM}$ ) was similar to the maize silage harvested with approx. $30-35 \%$ starch content. 
Table 1. Nutrient and energy content as well as microbiological condition of fresh tomato pomace and the different treatments (analyses were made from composite sample)

\begin{tabular}{llcccc}
\hline & & $\mathrm{TP}$ & $\mathrm{TP}+\mathrm{GMG}$ & $\mathrm{TP}+\mathrm{GMG}+\mathrm{S}$ & $\mathrm{TP}+\mathrm{GMG}+\mathrm{SI}$ \\
\hline $\mathrm{DM}$ & $\mathrm{g} \mathrm{kg}^{-1}$ & 269 & 363 & 376 & 363 \\
Crude protein (CP) & $\mathrm{g} \mathrm{kg}^{-1} \mathrm{DM}$ & 198 & 158 & 152 & 160 \\
Crude fibre (CF) & $\mathrm{g} \mathrm{kg}^{-1} \mathrm{DM}$ & 401 & 239 & 236 & 253 \\
$\mathrm{CP} / \mathrm{CF}$ & & 0.49 & 0.66 & 0.65 & 0.63 \\
Total starch & $\mathrm{g} \mathrm{kg}^{-1} \mathrm{DM}$ & 24 & 281 & 317 & 281 \\
Total carotene & $\mathrm{mg} \mathrm{kg}^{-1} \mathrm{DM}$ & 168 & - & - & - \\
Aerobic bacteria & $\log _{10} \mathrm{CFU} \mathrm{g} \mathrm{gM}^{-1} \mathrm{FM}$ & 5.00 & 5.00 & 5.56 & 7.16 \\
Moulds and yeasts & $\log _{10} \mathrm{CFU} \mathrm{g}{ }^{-1} \mathrm{FM}$ & 1.90 & 5.00 & 4.14 & 4.30 \\
$\mathrm{NE}_{\mathrm{m}}$ & $\mathrm{MJ} \mathrm{kg}^{-1} \mathrm{DM}$ & 4.88 & 6.84 & - & - \\
$\mathrm{NE}_{\mathrm{g}}$ & $\mathrm{MJ} \mathrm{kg}{ }^{-1} \mathrm{DM}$ & 2.53 & 4.26 & - & - \\
$\mathrm{NE}_{\mathrm{l}}$ & $\mathrm{MJ} \mathrm{kg}{ }^{-1} \mathrm{DM}$ & 4.46 & 6.33 & - & - \\
\hline
\end{tabular}

$\mathrm{TP}=$ fresh tomato pomace; $\mathrm{TP}+\mathrm{GMG}=$ tomato pomace mixed with ground maize grains (20\%); $\mathrm{TP}+\mathrm{GMG}+\mathrm{S}=$ tomato pomace mixed with ground maize grains $(20 \%)$ and salt $(0.5 \%) ; \mathrm{TP}+\mathrm{GMG}+\mathrm{SI}=$ tomato pomace mixed with ground maize grains (20\%), and applied with Sil All $4 * 4$ silage inoculants. $\mathrm{NE}_{\mathrm{m}}=$ Net energy for maintenance; $N E_{g}=$ Net energy for growth; $N E_{1}=$ Net energy for lactation. Data for energy calculation were available from Hungarian Feed Codex (2004).

\section{Fermentation quality}

Nominal size of the bales was: $1.20 \times 1.22 \mathrm{~m}$. High bale weight $\left(1120 \pm 12.6 \mathrm{~kg}\right.$ bale $\left.{ }^{-1}, \mathrm{n}=6\right)$, high density $(355 \pm 4.0$

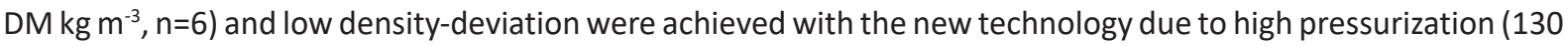
bar) and small particle size. Effluent production ranged between 6 and 10 litre per bale. High density and quick wrapping (within $120 \mathrm{sec}$ after bale-formation) had beneficial effect on fermentation quality. Nutrient content of tomato pomace silage according to the treatments are presented in Table 2. Changes in nutrient content of the treatments were due to the fermentation loss and losses with effluent.

DM content of the treatments was higher compared to fresh materials (by $12.4 \%, 8.9 \%$ and $3.6 \%$ in the treatments, respectively). Crude protein content decreased in the treatments, but the losses remained under $10 \%$. Crude fibre content decreased in TP+GMG (209 $\left.\mathrm{g} \mathrm{kg}^{-1} \mathrm{DM}\right)$ and TP+GMG+S (216 $\left.\mathrm{g} \mathrm{kg}^{-1} \mathrm{DM}\right)$ by 12.4 and 8.3\%, respectively. Experiment $\mathrm{TP}+\mathrm{GMG}+\mathrm{SI}$ showed the smallest loss during fermentation, with dry matter (3.6\%) and crude protein $(1.7 \%)$ compared to fresh material. Its protein content decreased to $157 \mathrm{~g} \mathrm{~kg}^{-1} \mathrm{DM}$, while its crude fibre content (267 $\mathrm{g} \mathrm{kg}^{-1} \mathrm{DM}$ ) was somewhat higher than that of in the original material ( $\left.253 \mathrm{~g} \mathrm{~kg}^{-1} \mathrm{DM}\right)$. Therefore, CP/CF decreased by $6.3 \%$ (0.59), while it increased in the control treatment (TP+GMG) and in treatment TP+GMG+S by 6.1 and $4.6 \%$, respectively. This increase was due to the low crude fibre content of the maize grains $\left(21.2 \mathrm{~g} \mathrm{~kg}^{-1} \mathrm{DM}\right)$.

Low fermentation intensity was found in the treatments with low lactic acid (16.3-20.5 $\left.\mathrm{g} \mathrm{kg}^{-1} \mathrm{DM}\right)$ and acetic acid (9.16-14.2 $\left.\mathrm{g} \mathrm{kg}^{-1} \mathrm{DM}\right)$ concentrations. The $\mathrm{pH}$ value was the most favourable in TP+GMG+SI (4.57), it was significantly lower than that of in control (4.97) and in treatment with salt $(5.13 ; p<0.01)$. The highest lactic acid (LA) concentration was found in TP+GMG+SI $\left(20.5 \mathrm{~g} \mathrm{~kg}^{-1} \mathrm{DM}\right)$, with the highest acetic acid (AA) concentration $\left(14.2 \mathrm{~g} \mathrm{~kg}^{-1}\right.$ $D M)$, and its lactic acid/acetic acid (LA/AA) ratio was the lowest (1.62) without significant differences between the treatments $(p>0.05)$. An undesirable fermentation process was found in the case of $0.5 \%$ salt treatment (butyric acid concentration: $3.70 \mathrm{~g} \mathrm{~kg}^{-1} \mathrm{DM}$ ) and in control tomato pomace baled silage (butyric acid concentration: 1.48 $\mathrm{g} \mathrm{kg}^{-1} \mathrm{DM}, p<0.05$, Tukey HSD post hoc test TP+GMG vs. TP+GMG+S $p<0.05 ; \mathrm{TP}+\mathrm{GMG}+\mathrm{S}$ vs. TP+GMG+SI $p=0.001$ ). Although LA/AA was the lowest in TP+GMG+SI, based on its $\mathrm{pH}$ value (4.57), absence of butyric acid and total acid content ( $\left.35.6 \mathrm{~g} \mathrm{~kg}^{-1} \mathrm{DM}\right)$, its fermentation was the most favorable.

There were significant differences between treatments in the case of fleig points $(p<0.05)$. Fleig points of TP+GMG+SI silage (97.2; very good quality) was significantly higher $(p<0.05)$ than that of the other two treatments. Fleig points of control silage was lower than TP+GMG+SI (87.9), based on this result it was very good, while fleig points of $\mathrm{TP}+\mathrm{GMG}+\mathrm{S}$ was even lower (81.5, good quality) because of the higher $\mathrm{pH}$ value.

The CP/CF of the different treatments did not reach the optimal 1.0 value, but CP/CF of tomato pomace mixed silage was much better than supplemental fodder fed frequently for large game species. CP/CF of maize silage generally used is $\mathbf{0 . 3 8}$, while this ratio of extensive, good quality meadow hay is 0.39 (according to Hungarian Feed Codex). Calculated CP/CF of tomato pomace mixed with ground maize grains at an inclusion rate of $20 \% \mathrm{w} / \mathrm{w}$ almost doubled $(0.70)$ the above-mentioned values. 
Table 2. Nutrient content and fermentation profile of baled tomato pomace silages

\begin{tabular}{|c|c|c|c|c|c|c|}
\hline & & TP+GMG & $\mathrm{TP}+\mathrm{GMG}+\mathrm{S}$ & $\mathrm{TP}+\mathrm{GMG}+\mathrm{SI}$ & SEM & $p$-value \\
\hline \multicolumn{7}{|c|}{ Nutrient content of tomato pomace silage according to the different treatments (composite samples) } \\
\hline DM & $\mathrm{g} \mathrm{kg}^{-1}$ & 408 & 409 & 375 & & \\
\hline Crude protein (CP) & $\mathrm{g} \mathrm{kg}^{-1} \mathrm{DM}$ & 146 & 147 & 157 & & \\
\hline Crude fibre (CF) & $\mathrm{g} \mathrm{kg}^{-1} \mathrm{DM}$ & 209 & 216 & 267 & & \\
\hline $\mathrm{CP} / \mathrm{CF}$ & & 0.70 & 0.68 & 0.59 & & \\
\hline Total starch & $\mathrm{g} \mathrm{kg}^{-1} \mathrm{DM}$ & 283 & 314 & 270 & & \\
\hline Total carotene & $\mathrm{mg} \mathrm{kg}{ }^{-1} \mathrm{DM}$ & 144 & 147 & 146 & & \\
\hline \multicolumn{7}{|c|}{ Fermentation profile of tomato pomace silage according to the different treatments $(n=3)$} \\
\hline $\mathrm{pH}$ & & $4.97^{\mathrm{a}}$ & $5.13^{\mathrm{a}}$ & $4.57^{b}$ & 0.09 & 0.004 \\
\hline Lactic acid (LA) & $\mathrm{g} \mathrm{kg}^{-1} \mathrm{DM}$ & 17.9 & 16.3 & 20.5 & 1.20 & 0.405 \\
\hline Acetic acid (AA) & $\mathrm{g} \mathrm{kg}^{-1} \mathrm{DM}$ & 9.16 & 9.63 & 14.2 & 1.40 & 0.291 \\
\hline Propionic acid & $\mathrm{g} \mathrm{kg}^{-1} \mathrm{DM}$ & $1.46^{\mathrm{a}}$ & $1.55^{\mathrm{a}}$ & $0.88^{b}$ & 0.11 & 0.004 \\
\hline Butyric acid & $\mathrm{g} \mathrm{kg}^{-1} \mathrm{DM}$ & $1.48^{\mathrm{a}}$ & $3.70^{\mathrm{b}}$ & $0.00^{\mathrm{a}}$ & 0.57 & 0.001 \\
\hline Volatile fatty acids & $\mathrm{g} \mathrm{kg}^{-1} \mathrm{DM}$ & 12.1 & 14.9 & 15.1 & 1.27 & 0.625 \\
\hline Organic acids & $\mathrm{g} \mathrm{kg}^{-1} \mathrm{DM}$ & 30.0 & 31.2 & 35.6 & 1.76 & 0.439 \\
\hline LA/AA & $\mathrm{g} \mathrm{g}^{-1}$ & 2.02 & 1.70 & 1.62 & 0.18 & 0.710 \\
\hline Fleig-points* & & $87.9^{\mathrm{a}}$ & $81.5^{a}$ & $97.2^{b}$ & 2.68 & 0.023 \\
\hline
\end{tabular}

Different letters $(\mathrm{a}, \mathrm{b})$ within a row indicate significant difference at the $p<0.05$ level; SEM $=$ Standard error of mean; LA/AA $=$ Lactic acid/ Acetic acid ratio; $\mathrm{TP}+\mathrm{GMG}=$ tomato pomace mixed with ground maize grains $(20 \%), \mathrm{TP}+\mathrm{GMG}+\mathrm{S}=$ tomato pomace mixed with ground maize grains $(20 \%)$ and salt $(0.5 \%), T P+G M G+S I=$ tomato pomace mixed with $20 \%$ ground maize grains, and applied with Sil All $4 * 4$ silage inoculants. Volatile fatty acids include acetic, propionic and butyric acid content together; organic acids include lactic acid and volatile fatty acids together. *Fleig points: 85-100 very good, 60-80 good, 55-60 medium, 25-40 satisfying, $<20$ worthless

\section{Feeding study}

Tomato pomace ensiled with $20 \%$ ground maize grains was a new type of food for game species, the individuals investigated had never eaten such silage before. Despite that, tomato pomace silage was consumed almost immediately, its total amount disappeared within two days after feeding, while maize silage remained there even for one week. Based on additional estimation of faeces density along 8 transects around feeding plots, there was no significant difference among the attendance of feeding plots by ungulates $(p=0.75)$.

Proportion of the different food categories in the faeces of ungulates are shown in Figure 1. Tomato was the most common component in the diet of red deer (54.2-66.8\%, except in March: $28.2 \%$ ) and fallow deer (33.2-45.7\%, except in March: 6.4\%). It was also important in the diet of wild boar (27.2-76.2\%). Tomato fragments occurred rarely in the faeces of mouflon between November and January $(5.1-13.3 \%)$, but not in February $(54.6 \%)$ and March (37.4\%). The most common component in its diet was monocot plant material (8.9-58.6\%).

In the case of red deer and wild boar, the proportion of tomato items was significantly higher compared to the other plant fragments in the faeces (Dunnett's T3 test: tomato pomace silage vs. other plant categories: $p<0.01$ in the case of red deer; $p<0.05$ in the case of wild boar). In these species and also in case of fallow deer there were significant differences between consumption of tomato pomace and maize silage, as well as tomato pomace and dicotyledonous plants (Dunnett's T3 test: $p<0.05$ ). The proportion of tomato pomace in the faeces of red deer increased in the first four months, but it significantly decreased in March 2010 (Tukey HSD test: February vs. March $p<0.05)$, similarly to fallow deer without any significant difference $(p>0.05)$.

Proportions of food components in the diet of mouflon were almost the opposite to the other two ruminants. The proportion of tomato fragments was low in the first three months (5.1-13.0\%), the two main diet categories were then monocotyledon and woody plants $(47.1-58.6 \%$ and $20.2-31.9 \%$, respectively). However, the proportion of tomato pomace silage increased greatly in February and March (54.6 and 37.4\%, respectively), in these months it was the most common component, but significant differences were not found (Dunnett's T3 test: $p>0.05$, November vs. February: $p=0.062$, January vs. February: $p=0.061$ ). There was no significant difference between the proportion of tomato and the fragments from other four categories (Dunnett's T3 test: $p>0.05$ ). 
The proportion of maize silage in the faeces was low in almost all cases (red deer: 0.9-8.4\%; fallow deer: 0.6-7.7\%; mouflon: 2.6-6.6\%). Its presence was the highest in case of wild boar (5.7-33.3\%), although it did not exceed the proportion of any other fragments in the faeces.

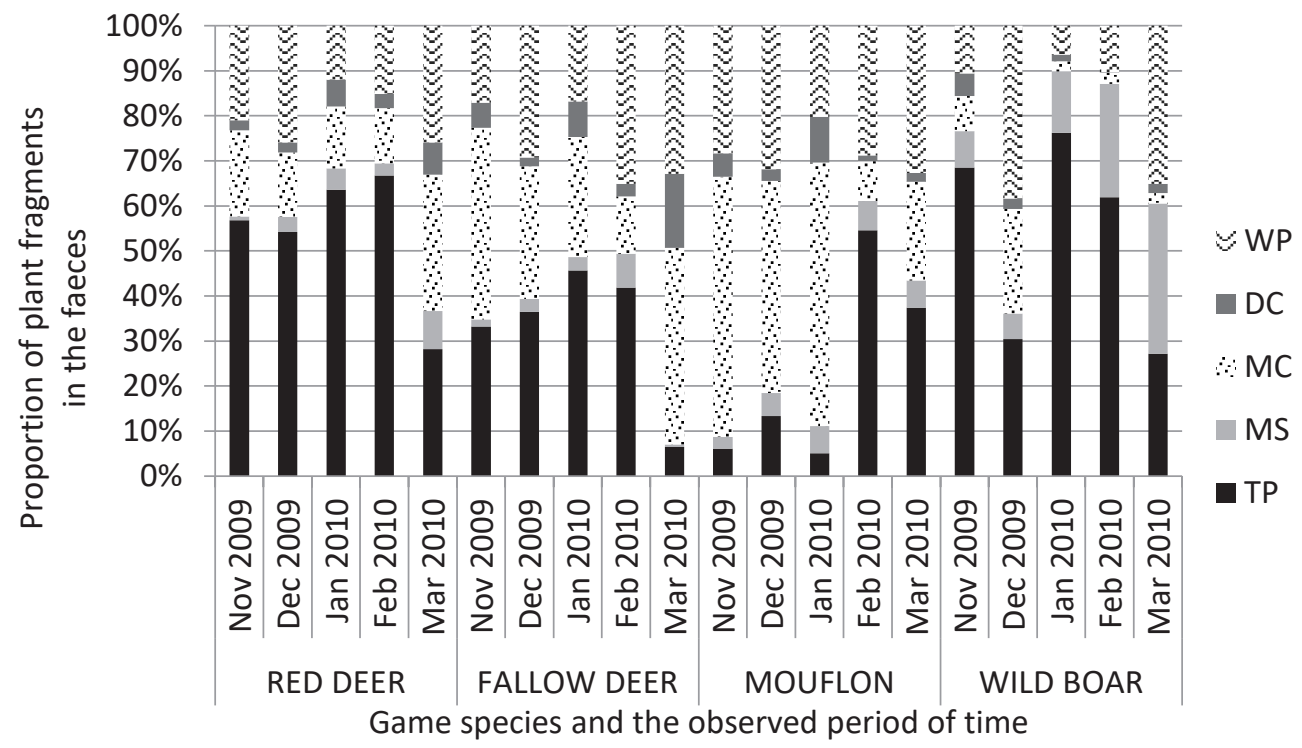

Fig. 1. Proportion of different food categories in the faeces of ungulate species in the study period $(\mathrm{TP}=$ tomato pomace silage, $\mathrm{MS}=$ maize silage, $\mathrm{MC}=$ monocotyledon, $\mathrm{DC}=$ dicotyledon, $\mathrm{WP}=$ woody plants)

\section{Discussion}

\section{Nutritional and fermentation quality of tomato pomace}

Our first hypothesis was, that tomato pomace mixed with ground maize grains increases the dry matter content; as well as improves CP/CF above 1.0. The results supported the first part of the hypothesis. The dry matter content of tomato pomace was relatively low (26.9\%), but mixing with ground maize grains, it was in the optimal DM range for fermentation (36-37\%). Although the quality of tomato pomace varies amongst countries based on the processing method, tomato varieties, ripening stages, etc., the nutrient content of tomato pomace in our study was compatible with those reported by Mirzaei-Aghsaghali and Maheri-Sis (2008). We agree with Hadjipanayiotou (1994), who concluded that it can be a potential protein source in animal nutrition, and we verify the findings of Elliott et al. (1981) who stated that tomato pomace silage is a good source of fibre.

However, we do not confirm the finding of Hadjipanayiotou (1994) who stated that tomato pomace silage can be a potential energy source in animal nutrition. Tomato pomace itself has a relatively low energy content, but adding ground maize grains at $20 \%$ to tomato pomace increased the energy content of the silage. It was assumed that $\mathrm{CP} / \mathrm{CF}$ exceeds the optimal value, but according to our results it was not the case. Although CP/CF of mixed silage exceeded that of the tomato pomace, it did not reach the optimal value. Despite that, its CP/CF is even better than that of usually fed supplementary foods, e.g. maize silage.

Our second hypothesis was that mixed material ferments well. According to the results on fermentation quality, wet tomato pomace had a limited fermentation capacity, but under anaerobic conditions it was possible to store it for a long period (minimum of 100 days) with a good microbial status. It is recommended to use dried ground cereal as an additive (20\%) to increase dry matter and energy content, moreover to improve volatile fatty acid composition of the wet tomato pomace silage. Treatment with salt significantly increased the butyric acid concentration of the silage, therefore the application of salt is not recommended. The silage inoculant effectively inhibited the production of butyric acid, and reduced the protein loss by $6 \%$ compared to the control. Consequently, the application of a biological additive is recommended in order to improve silage fermentation quality in baled tomato pomace silages. It is also recommended to analyze the fermentation of tomato pomace mixed with other by-products. Ensiling tomato pomace with another by-product could reduce the costs and increase CP/CF. 
Using of the new baling system confirmed our third hypothesis, since well-shaped and stable bales from such a wet by-product as fresh tomato pomace with a small particle size (initial dry matter range of the mix was 363$376 \mathrm{~g} \mathrm{~kg}^{-1}$ ) could be made. It is recommended to puncture the bales and remove the effluent within one day after baling and not later, because then effluent can be removed but the plastic wrap is still flexible enough to shrink.

\section{Feeding study}

Our last hypothesis was that this new type of silage will be consumed by ungulate species, even in a higher quantity than traditional supplementary foods. Our results supported our expectations. We evaluated the consumption of tomato pomace silage by wild ungulate species adapted to natural forage diets. We revealed that wild ungulates consume tomato pomace in a relatively high proportion, and they prefer it to the most common supplementary feed i.e. maize silage. Tomato pomace silage was consumed almost immediately after placing it in the feeding plots, while maize silage remained there for several days (even for a week). No obvious impact of ensiling treatments on consumption of tomato pomace silage or on health status of ungulates was recognised. We confirmed the statement of Roosendaal (1992), as well as Dubois and Fraser (2013), who found that supplementary winter feeding could be very important for big game species in intensively managed hunting preserves with dense game populations.

In our study red deer, fallow deer, and wild boar consumed significantly more tomato pomace silage than maize silage or natural forage. The consumption rate of the supplementary fodder was much higher than it was found earlier in free-living deer populations (less than 10\%, Katona et al. 2010, Katona et al. 2014). It verified that we have to make distinctions between fenced and unfenced areas in terms of the importance of supplementary winter feeding. The food selection of wild ruminants corresponded to Hofmann's categorisation (1989), who classified the ruminants according to feeding type. He described red and fallow deer as intermediate feeders, meanwhile mouflon as a grass/roughage eater. Our results were in accordance with his classification, since red and fallow deer consumed the mixed diet. Mouflon consumed the most monocot (fibrous) plant material. Another potential reason for those dietary differences might have been that red and fallow deer used the feeding plots more intensively than mouflon due to their potentially different strategies for avoidance of competition and predators. Low consumption rate of natural forage could be due to the fact that the dominant shrub species on the investigated area are blackthorn and hawthorn. These species are not preferred by game species, these shrub species are mainly used to provide a hiding-place for wild ruminants, but not food.

Low consumption of maize silage could show that this may not be an optimal supplementary feed for game species. Maize silage is rich in fibre, but even the grass/roughage eater mouflon preferred natural forage (woody plants, monocots) to it. Most maize silage was consumed by wild boar. However, the category of maize silage included the maize silage itself and the maize grain scattered on the ground, so we could not unambiguously decide from which one the consumption rate had been derived. We assumed that the highest consumption rate in March (33.3\%) was also related to maize grain and not only to the maize silage itself. Consequently, consumption of maize silage may have been overestimated and that of tomato pomace silage may have been underestimated.

Based on our findings about the high consumption rate of tomato pomace silage we concluded that supplementary feeding is not only important in fenced areas, but the nutrient content of the supplementary food (mainly its crude protein and crude fibre, maybe energy content) can also be important in the food choice of free-living ungulates. Although CP/CF of tomato pomace silage did not reach the 1-1.5 ratio - which may be optimal for wild ruminants - it was better than that of maize silage or hay. Despite the fact that ungulates consumed tomato pomace silage in the hunting preserve, it did not necessarily mean that it is an optimal supplementary food for them. It could be possible that it was the food, which was available in a greater amount in the hunting preserve in the observed period of time. If we accept that we have to give supplementary fodder for game species in fenced areas, then we have to give them such supplementary foods that satisfy all their needs. Tomato pomace silage may be a good solution, but does not overlap the whole range of the dietary requirements of the studied ungulate species. Because of this we emphasize the fundamental importance of the natural food resources of the habitat, such as the understory food supply or forest edge vegetation. 


\section{Conclusion}

Our results suggest that tomato pomace can be preserved and fermented well mixed with ground maize grains. Based on the results, it can be concluded, that the new bale-forming technology provides stable wet tomato pomace silage ( $20 \%$ ground maize grains) for long term storage. Moreover, the transportable baled silage with considerable energy and protein concentration, as well as carotene source can have beneficial effects for game feeding during the winter time. According to the nutrient content and consumption of tomato pomace silage by wild game species, it can be a suitable supplementary fodder for game, but further more detailed chemical analyses would be required.

\section{Acknowledgements}

We would like to thank Aranyfácán Product Co. Ltd., Hatvan for funding the project. We are also grateful to all colleagues and students of Szent István University, Institute for Wildlife Conservation participating in the research for their technical help. We are thankful to János Halas for helping us in the field-work. Renáta Lakatos, Péter Kelemen and Szilveszter Kazinczy took part in the collection of the field samples; we are grateful to them. The research was supported by the Research Centre of Excellence (1476-4/2016/FEKUT).

\section{References}

Alipayo, D., Valdez, R., Holechek, J.L. \& Cardenas, M. 1992. Evaluation of microhistological analysis for determining ruminant diet botanical composition. Journal of Range Management 45: 148-152. https://doi.org/10.2307/4002773

Asnani, K.M., Klips, R.A. \& Curtis, P.S. 2006. Regeneration of woodland vegetation after deer browsing in Sharon Woods Metro Park, Franklin County, Ohio. Ohio Journal of Science 106: 86-92.

Baker, D.L. \& Hobbs, N.T. 1985. Emergency feeding of mule deer during winter: tests of a supplemental ration. Journal of Wildlife Management 49: 934-942. https://doi.org/10.2307/3801374

Barroso, F.G., Martinez, T., Moyano, F.J., Megias, M.D., Madrid, M.J. \& Hernandez, F. 2005. Silage potential of horticultural byproducts for the feeding of small ruminants in southern Spain. In: Lillak, R., Viiralt, R., Linke, A., Geherman, V. (eds). Integrating efficient grassland farming and biodiversity. Proceedings of the 13th International Occasional Symposium of the European Grassland Federation. Tartu, Estonia, 29-31 August 2005.

Butler, E.A., Jensen, W.F., Johnson, R.E. \& Scott, J.M. 2008. Grain overload and secondary effects as potential mortality factors of moose in North Dakota. Alces 44: 73-79.

Chen, H., Ma, J., Li, F., Sun, Z., Wang, H., Lou, L., Li, F. 1998: Seasonal composition and quality of red deer Cervus elaphus diets in northeastern China. Acta Theriologica 43: 77-94. https://doi.org/10.4098/AT.arch.98-6

Chumpawadee, S. 2009. Degradation characteristics of tomato pomace, soybean hull and peanut pod in the rumen using nylon bag technique. Pakistan Journal of Nutrition 8: 1717-1721. https://doi.org/10.3923/pjn.2009.1717.1721

Csányi, S. 2015. A 2014/2015. Vadászati év vadgazdálkodási eredményei valamint a 2015. Vadállomány becslési adatok és vadgazdálkodási tervek. http://ova.info.hu/vg_stat/VA-2014-2015m.pdf (in Hungarian).

Csányi, S. \& Lehoczki, R. 2010. Ungulates and their management in Hungary. In: Apollonio, M., Andersen, R., Putman, R. (eds): European ungulates and their managament in the 21st century. Cambridge University Press p. 291-318.

Denek, N. \& Can, A. 2006. Feeding value of wet tomato pomace ensiled with wheat straw and wheat grain for Awassi sheep. Small Ruminant Research 65: 260-265. https://doi.org/10.1016/j.smallrumres.2005.06.024

Dubois, S. \& Fraser, D. 2013. A framework to evaluate wildlife feeding in research, wildlife management, tourism and recreation. Animals 3: 978-994. https://doi.org/10.3390/ani3040978

Elliott, J., Mulvihill, E., Dumcan, C., Forsythe, R. \& Kritchevsky, D. 1981. Effect of tomato pomace and mixed vegetable pomace on serum and liver cholesterol in rats. Journal of Nutrition 111: 2203-2211.

FAOSTAT 2013. http://faostat3.fao.org/browse/Q/QC/E

González-Hernández, M.P. \& Silva-Pando, F.J. 1999. Nutritional attributes of understory plants known as components of deer diets. Journal of Range Management 52: 132-138. https://doi.org/10.2307/4003506

Hadjipanayiotou, 1994. Laboratory evaluation of ensiled olive cake, tomato pulp and poultry litter. Livestock Research for Rural Development 6. http://www.Irrd.org/Irrd6/2/cyprus1.htm. Accessed September 092011.

Hasimoglu, S., Cakir, A., Aksoy, A. \& Ozen, N. 1979. Domates salcası artiklarinin (kuru domates posasi) kaba yem olarak kullanilma olanagi uzerinde bir calısma (The possibilities of using tomato pomace as roughage in ruminant rations). Journal of the Faculty of Agriculture 10: 139-150.

Hofmann, R. R. 1989. Evolutionary steps of ecophysiological adaptation and diversification of ruminants: a comparative view of their digestive system. Oecologica 78: 443-457. https://doi.org/10.1007/BF00378733

ISO 4833 2003. Microbiology of food and animal feeding stuffs. Horizontal method for the enumeration of micro-organisms. Colony-count technique at 30 degrees $C$.

Hungarian Food Codex (Codex Pabularis Hungaricus) 2004. Volume 2. Published by Hungarian Codex Committee. 158 p. 
Katona, K. \& Altbäcker, V. 2002. Diet estimation by faeces analysis: sampling optimisation for the European hare. Folia Zoologica 51: 11-15.

Katona, K., Gál-Bélteki, A., Terhes, A., Bartucz, K., Szemethy, L. 2014. How important is supplementary feed in winter diet of red deer? A test in Hungary. Wildlife Biology 20: 326-334. https://doi.org/10.2981/wlb.00053

Katona, K., Szemethy, L., Béltekiné Gál, A., Terhes, A. \& Bartucz, K. 2010. Kiegészítő takarmányozás szerepe a gímszarvas téli takarmányozásában. (The role of supplementary feed in the winter diet of red deer). Vadbiológia 14: 19-28.

Kilic, A. 1984. Silo Yemi (Silage Feed). Bilgehan Press, İzmir, Turkey. 350 p.

Mátrai, K., Katona, K., Szemethy, L., Sonkoly, K., Szabó, L., Schally, G., Galló, J. \& Bleier, N. 2013. Does diet composition of red deer (Cervus elaphus) differ between fenced and unfenced areas? Review on Agriculture and Rural Development 2: 143-147.

Mátrai, K., Koltay, A., Tóth, S. \& Vízi, Gy. 1986. Key based on leaf epidermal anatomy for food habit studies of herbivores. Acta Botanica Hungarica 23: 255-271.

Mátrai, K., Szemethy, L., Tóth, P., Katona, K. \& Székely, J. 2004. Resource use by red deer in lowland non-native forests, Hungary. Journal of Wildlife Management 68: 879-888. https://doi.org/10.2193/0022-541X(2004)068[0879:RUBRDI]2.0.CO;2

Mirzaei-Aghsaghali, A. \& Maheri-Sis, N. 2008. Nutritive value of some agro-industrial by-products for ruminants - A review. World Journal of Zoology 3: 40-46.

MSZ 6830-14:1984. Animal feeding stuffs. Determination of nutritive value. Determination of the carotene and xanthophyl content. MSZ 6830-18:1988. Animal feeding stuffs. Determination of nutritive value. Determination of starch content.

MSZ 6830-39:1986. Animal feeding stuffs. Determination of nutritive value. Determination of acetic acid, butyric acid and lactic acid content in ensilaged animal feeding stuffs.

MSZ 6830-4:1981. Animal feeding stuffs. Determination of nutritive value. Determination of nitrogen content for the calculation of crude protein content.

MSZ EN ISO 6865:2001. Animal feeding stuffs. Determination of crude fibre content. Method with intermediate filtration (ISO 6865:2000).

MSZ ISO 6496:2001. Animal feeding stuffs. Determination of moisture and other volatile matter content.

MSZ ISO 7954:1999. Microbiology. General guidance for enumeration of yeasts and moulds. Colony count technique at $25^{\circ} \mathrm{C}$.

Omer, H.A.A. \& Abdel-Magid, S.S. 2015. Incorporation of dried tomato pomace in growing sheep rations. Global Veterinaria 14: 1-16.

Orosz, Sz., Szúcsné-Péter, J., Owens, V. \& Bellus, Z. 2008. Recent developments in harvesting and conservation technology for feed and biomass production of perennial forage crops. A review. Biodiversity and Animal Feed: Future Challenges of Grassland Production. Proceedings of the 22nd General Meeting of the European Grassland Federation, Uppsala, Sweden 9-12 June. Grassland Science in Europe 13: 529-548.

Owens, F.N., Secrist, D.S., Hill, W.J. \& Gill, D.R. 1998. Acidosis in cattle - A review. Journal of Animal Science 76: 275-286. https://doi.org/10.2527/1998.761275x

Putman, R.J. \& Staines, B.W. 2004. Supplementary winter feeding of wild red deer Cervus elaphus in Europe and North America: justifications, feeding practice and effectiveness. Mammal Review 34: 285-306.

https://doi.org/10.1111/j.1365-2907.2004.00044.x

Rajský, M., Vodňanský, M., Hell, P., Slamečka, J., Kropil, R. \& Rajský, D. 2008. Influence of supplementary feeding on bark browsing by red deer (Cervus elaphus) under experimental conditions. European Journal of Wildlife Research 54: 701-708. https://doi.org/10.1007/s10344-008-0199-2

Rehbinder, C. \& Ciszuk, P. 1985. Supplementary feeding of roe deer (Capreolus capreolus L.) with late harvested hay. A pilot study. Rangifer 5: 6-14. https://doi.org/10.7557/2.5.2.540

Roosendaal, B. 1992. Spesfeed: Wildlife nutrition and feeding. http://www.alzu.co.za/img/WNutrition.pdf. Accessed August 192011.

Schoonveld, G.G., Nagy, J.G. \& Bailey, J.A. 1974. Capability of mule deer to utilize fibrous alfalfa diets. Journal of Wildlife Management 38: 823-829. https://doi.org/10.2307/3800051

Steyaert, S. M.J.G., Kindberg, J., Jerina, K., Krofel, M., Stergar, M., Swenson, J. E. \& Zedrosser, A. 2014. Behavioral correlates of supplementary feeding of wildlife: Can general conclusions be drawn? Basic and Applied Ecology 15: 669-676. https://doi.org/10.1016/j.baae.2014.10.002

Szemethy. L., K., Mátrai, Katona, K., Orosz, Sz. 2003. Seasonal home range shift of red deer hinds, Cervus elaphus: are there feeding reasons? Folia Zoologica 52: 249-258.

Szemethy, L., Katona, K., Mátrai, K., Sonkoly, K., Szabó, L., Schally, G., Galló, J. \& Bleier, N. 2013. Is seasonal diet composition of red deer (Cervus elaphus) affected by game preservation? Proceedings of 2 nd International Symposium on Hunting: Modern aspects of sustainable management of game populations. p. 169-172.

Tahmasbi, R., Nasiri, H., Naserian, A. \& Saremi, B. 2002. Effect of different levels of mixed corn plant and tomato pomace on milk production and composition in Holstein dairy cows. Journal of Animal Science 80 (Suppl. 1) 299 p.

Valizadeh, R. \& Sobhanirad, S. 2009. The potential of agro-industrial by-products as feed sources for livestock in Khorasan Razavi province of Iran. Journal of Animal and Veterinary Advances 8: 2375-2379.

Weston, T. 2012. Feeding wild deer. Keeping the balance. Magazine for National Gamekeepers Organisation. 39 p. http://www. nationalgamekeepers.org.uk/media/uploads/cat-249/KtBautumn12-p39FeedingWildDeer.pdf . Accessed July 22, 2014.

White, M.A. 2012. Long-term effects of deer browsing: composition, structure and productivity in a northeastern Minnesota oldgrowth forest. Forest Ecology and Management 269: 222-228. https://doi.org/10.1016/j.foreco.2011.12.043 
Wobeser, G. \& Runge, W. 1975. Rumen overload and rumenitis in white-tailed deer. Journal of Wildlife Management 39: 596-600. https://doi.org/10.2307/3800403

Woolf, A. \& Kradel, D. 1977. Occurrence of rumenitis in a supplementary fed white-tailed deer herd. Journal of Wildlife Diseases 13: 281-285. https://doi.org/10.7589/0090-3558-13.3.281

Ziaei, N. \& Molaei, S. 2010. Evaluation of nutrient digestibility of wet tomato pomace ensiled with wheat straw compared to alfalfa hay in Kermani sheep. Journal of Animal and Veterinary Advances 9: 771-773.

https://doi.org/10.3923/javaa.2010.771.773 